\title{
HIGH-INTENSITY MAGNETIC SEPARATION OF LIMONITE IRON ORES
}

\author{
V.M. MALIY AND I.P. BOGDANOVA \\ Mekhanobrchermet Institute, Krivoy Rog 324087, Ukraine
}

(Received March 10, 1992)

\begin{abstract}
Results of investigation into the development of HIMS technology for separation of weakly magnetic finely disseminated limonite iron ores are discussed.
\end{abstract}

\section{INTRODUCTION}

Among the world iron ore deposits, the limonite ores are the third most abundant source of iron. The overwhelming part of these ores is represented by low-grade varieties which cannot be used in iron and steel industry without preliminary beneficiation.

Low contrast properties of metallic and non-metallic minerals, fine dissemination and their tendency to sliming represent basic difficulties in the development of technologies for beneficiation of these ores.

Successful application of high-intensity magnetic separation in beneficiation of hematite ores forms a basis for a wider use of this technological process for treatment of such difficult-to-treat ores as limonite.

This article presents the results of investigations performed at the Mekhanobrchermet Institute to develop a technology for beneficiation of the Kremikovsky (Bulgaria) and Kerch (Ukraine) limonite ores by high-intensity magnetic separation.

\section{MAGNETIC SEPARATION OF LIMONITE ORES FROM THE} KREMIKOVSKY DEPOSIT

Two samples of limonite ores representing 60 per cent of iron ore from the deposit were investigated. The ores are characterized by varying mineral composition, textural and structural peculiarities and complex mineral intergrowth. 
The metallic minerals are represented by iron hydroxides, hematite, manganese oxides and hydroxides containing barium and lead, magnetite, plumbojarosite, clayey minerals, barite and quartz. Mineral composition of the ore is shown in Table I, while the chemical composition is given in Table II. Tables III and IV summarize macroscopic description and morphological characteristics, respectively.

TABLE I Mineral composition of the ore

\begin{tabular}{ll} 
Mineral/Iron & Percentage \\
\hline & \\
Magnetite & $0.5 / 0.4$ \\
Hematite & $14.4 / 10.1$ \\
Iron hydroxides & $29.8 / 18.5$ \\
Silicates & $5.8 / 0.4$ \\
Oligonite & $1.3 / 0.2$ \\
Sulphides & $0.4 / 0.1$ \\
Manganese oxides and hydroxides & 8.8 \\
Plumbojarosite & 0.7 \\
Barite & 24.4 \\
Non-metallic carbonates & 4.7 \\
Quartz & 9.0 \\
Apatite & 0.2 \\
\hline
\end{tabular}

TABLE II Chemical composition of the ore

\begin{tabular}{ll} 
Element & Percentage \\
\hline $\mathrm{Fe}$ & 29.9 \\
$\mathrm{Mn}$ & 5.6 \\
$\mathrm{Cu}$ & 0.01 \\
$\mathrm{~Pb}$ & 0.3 \\
\hline
\end{tabular}

To evaluate the metallurgical properties of the ore, sedimentation, gravity separation (in heavy suspensions with specific gravities of 2800, 4000 and 4200 $\mathrm{kg} / \mathrm{m}^{3}$ ) and magnetic separation (magnetic flux density up to $1.2 \mathrm{~T}$ ) were carried out and magnetic characteristics were measured. 
TABLE III Macroscopic description of the samples

\begin{tabular}{lll}
\multicolumn{1}{c}{ Varieties } & Structure & Texture \\
\hline Limonite-hematite & $\begin{array}{l}\text { Colloform, } \\
\text { streaky-spotted }\end{array}$ & $\begin{array}{l}\text { Cryptocrystalline, } \\
\text { highly fine-grained }\end{array}$ \\
Hematite-limonite & $\begin{array}{l}\text { Colloform, } \\
\text { streaky-spotted }\end{array}$ & $\begin{array}{l}\text { Cryptocrystalline, } \\
\text { highly fine-grained }\end{array}$ \\
Limonite-ochreous & $\begin{array}{l}\text { Streaky-spotted, } \\
\text { lens-shaped }\end{array}$ & $\begin{array}{l}\text { Cryptocrystalline, } \\
\text { highly fine-grained }\end{array}$ \\
Siderite & $\begin{array}{l}\text { Massive } \\
\text { semioxidized }\end{array}$ & $\begin{array}{l}\text { Fine-grained } \\
\text { pseudooolitic }\end{array}$ \\
Barite & Massive & $\begin{array}{l}\text { Coarse-grained, } \\
\text { highly fine-grained }\end{array}$ \\
\hline
\end{tabular}

TABLE IV Morphological characterisics of the varieties

\begin{tabular}{llll} 
Varieties & $\begin{array}{l}\text { Morphological } \\
\text { character. }\end{array}$ & Colour & $\begin{array}{l}\text { Types of mineral } \\
\text { intergrowths }\end{array}$ \\
\hline $\begin{array}{l}\text { Limonite- } \\
\text { hematite }\end{array}$ & $\begin{array}{l}\text { Porous, } \\
\text { ochreous }\end{array}$ & $\begin{array}{l}\text { Black with } \\
\text { reddish hint }\end{array}$ & $\begin{array}{l}\text { Nests, veins } \\
\text { hydrox.inclusions }\end{array}$ \\
$\begin{array}{l}\text { Hematite- } \\
\text { limonite }\end{array}$ & $\begin{array}{l}\text { Porous, } \\
\text { ochreous }\end{array}$ & $\begin{array}{l}\text { Light to } \\
\text { dark brown }\end{array}$ & $\begin{array}{l}\text { Nests, veins, } \\
\text { hydrox.inclusions }\end{array}$ \\
$\begin{array}{l}\text { Limonite- } \\
\text { ochreous }\end{array}$ & $\begin{array}{l}\text { Ochreous, } \\
\text { porous }\end{array}$ & $\begin{array}{l}\text { Yellow,gre- } \\
\text { enish yellow }\end{array}$ & $\begin{array}{l}\text { Veins,nests, } \\
\text { limonite lens }\end{array}$ \\
$\begin{array}{l}\text { Siderite } \\
\text { semioxidized }\end{array}$ & Dense & $\begin{array}{l}\text { Brownish, } \\
\text { cream-coll. } \\
\text { in fracture } \\
\text { White, }\end{array}$ & $\begin{array}{l}\text { Pseudooolite, } \\
\text { cemented with } \\
\text { carbonate mass } \\
\text { Veins, nests, } \\
\text { barite }\end{array}$ \\
hydrox. & Dense & grey & $\begin{array}{c}\text { hydrox films and } \\
\text { dendrites }\end{array}$ \\
\hline
\end{tabular}


The results of gravity separation indicate the presence of iron minerals in fractions of specific gravity of 2800 to $4200 \mathrm{~kg} / \mathrm{m}^{3}$; fractions with specific gravity greater than $4200 \mathrm{~kg} / \mathrm{m}^{3}$ are rich in barite.

Magnetic characteristics of the concentrate which was subjected to magnetic separation (at the magnetic field intensity of $80 \mathrm{kA} / \mathrm{m}(1 \mathrm{kOe})$ ) are as follows:

Specific magnetization: $0.128-0.450 \mathrm{Am}^{2} / \mathrm{kg}$

Specific magnetic susceptibility: $1.2 \times 10^{-6}-4.9 \times 10^{6} \mathrm{~m}^{3} / \mathrm{kg}$.

The maximum values of specific magnetization and specific magnetic susceptibility are characteristic for $+10 \mu \mathrm{m}-45 \mu \mathrm{m}$ fraction, as can be seen in Figure 1 .

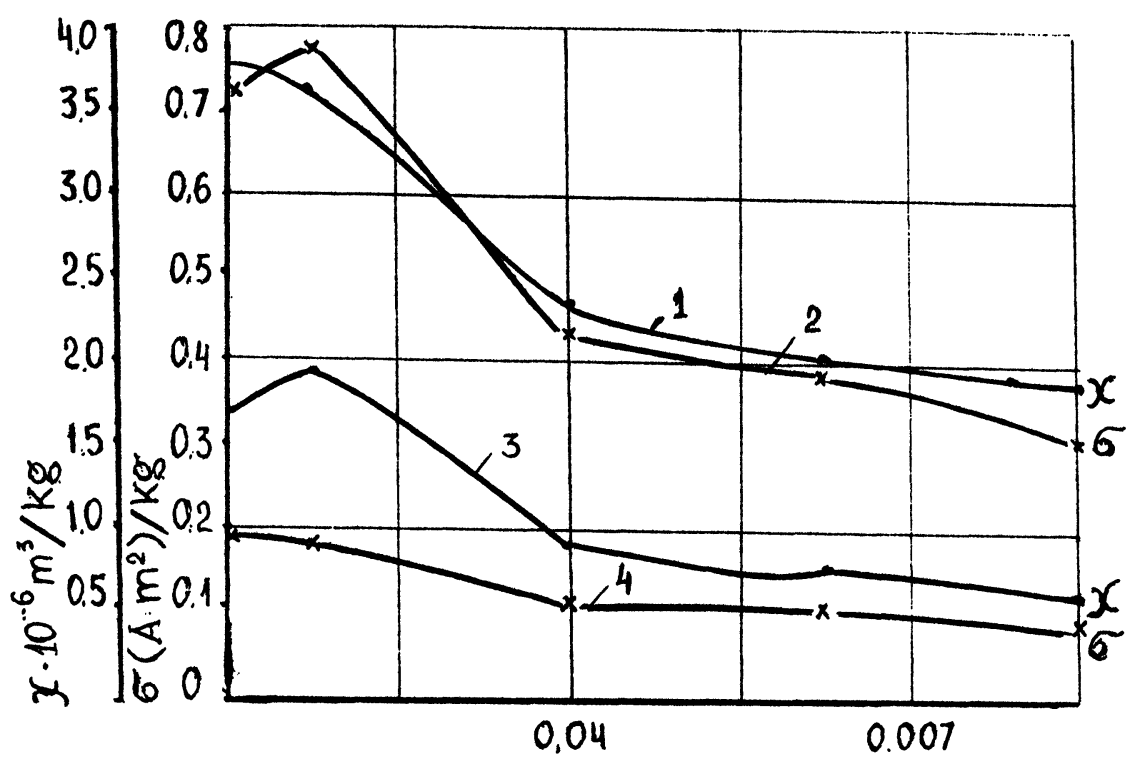

FIGURE 1 The dependence of specific magnetic susceptibility and specific magnetization on size of the material, at magnetic field intensity of $80 \mathrm{kA} / \mathrm{m}$ (1 kOe) (curves 1 and 3), and $800 \mathrm{kA} / \mathrm{m}$ (10 kOe) (curves 2 and 4 ).

Magnetic characteristics of the products investigated depend both on magnetic properties of gangue minerals and on the presence of magnetite. 
Laboratory tests were performed using a laboratory magnetic separator with horizontal magnetic field, height of the separation zone of $220 \mathrm{~mm}$ and the maximum magnetic flux density of $1.5 \mathrm{~T}$ in the separation zone.

A three-rotor magnetic separator with horizontal rotor was used in pilot-plant tests. The height of the separation zone in each rotor was $220 \mathrm{~mm}$. The maximum magnetic flux density in the upper rotor was $0.4 \mathrm{~T}$ while $1.4 \mathrm{~T}$ was available in the other two rotors.

The non-magnetic fractions from the upper and middle rotor were cleaned in middle and lower rotors, respectively. Each rotor has two independent power supplies and, consequently, six operations can be performed simultaneously.

The 6-ERM 35/315 separator is a commercial prototype of which six units have been installed at the Central Mining and Beneficiation Complex in Krivoy Rog.

The following matrices were used in the laboratory and pilot-plant magnetic separators:

Grooved plates with $3.2 \mathrm{~mm}$ pitch and $2 \mathrm{~mm}$ gap

Grooved plates with $3.2 \mathrm{~mm}$ pitch and $4 \mathrm{~mm}$ gap

Combination of grooved plates and expanded metal sheets.

Size distribution in laboratory tests was maintained at 30 to 65 per cent $-74 \mu \mathrm{m}$, the feed density ranged between 35 and 40 per cent solids.

It was found that when the concentration of the final size fraction in the feed increases, the iron content in the product and the recovery of iron increase. Further size reduction results in a considerable reduction of the recovery, as a result of low efficiency of recovery of $-10 \mu \mathrm{m}$ fraction.

When the gap between the plates is reduced from $4 \mathrm{~mm}$ to $2 \mathrm{~mm}$, a marked increase in the recovery of iron is observed, while the quality of the product decreases.

The use of the combination matrix which has a higher magnetic field gradient compared to grooved plates matrix results in an increase in iron recovery, as a consequence of the presence of fine grains of feebly magnetic minerals. Results of magnetic separation tests are summarized in Table $\mathrm{V}$.

Chemical composition of the concentrate produced in pilot- plant tests is given in Table VI. The recovery of iron into the concentrate was 74.1 per cent. 


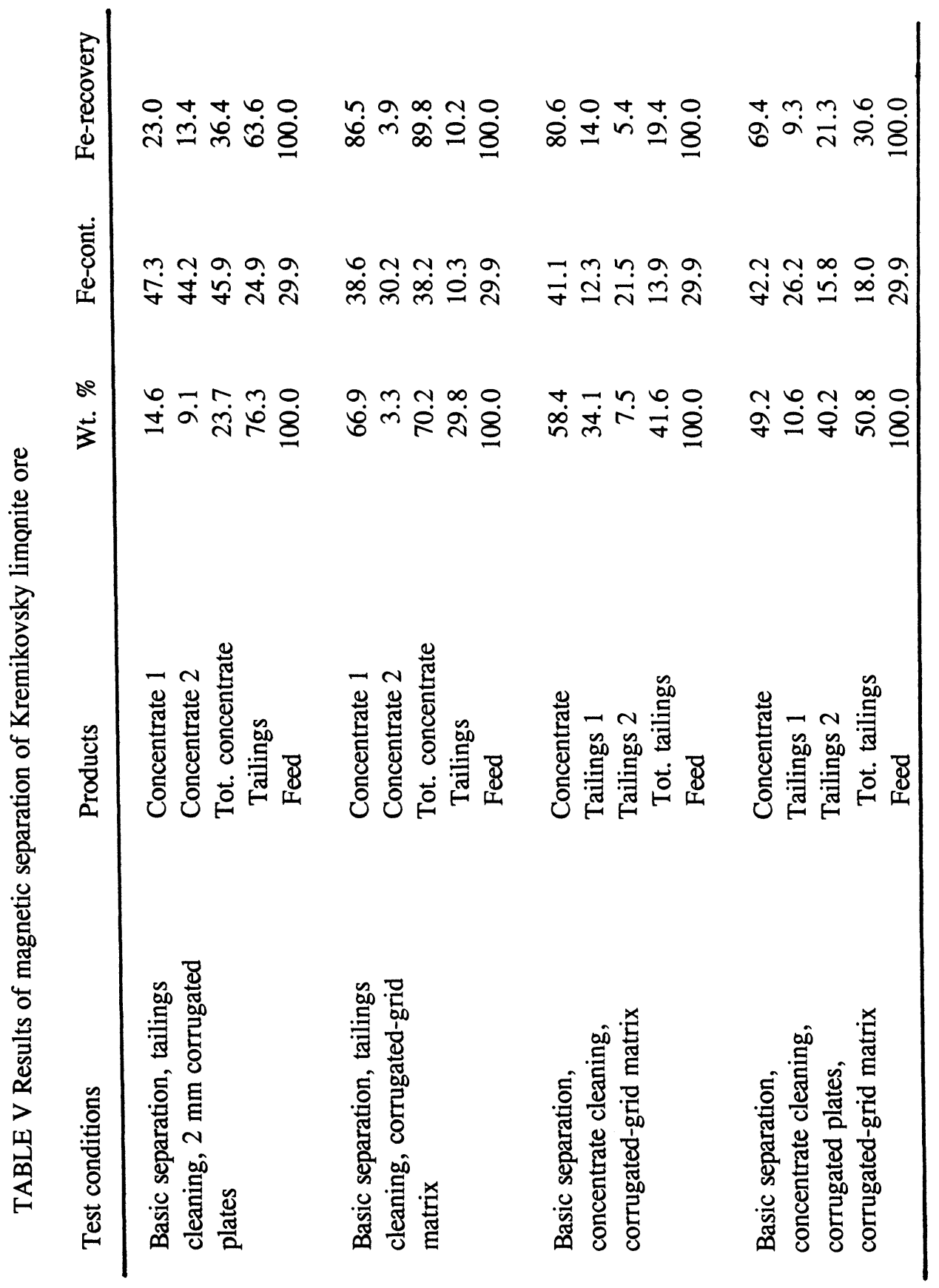


TABLE VI Chemical composition of the concentrate

\begin{tabular}{lr} 
Product & Percentage \\
\hline Fe total & 42.2 \\
Fe magnetic & 0.3 \\
Fe hematite + hydroxide & 40.8 \\
Fe carbonate + silicate & 0.3 \\
Fe ignited & 46.5 \\
$\mathrm{Mn}$ & 7.6 \\
$\mathrm{BaO}$ & 2.5 \\
$\mathrm{SiO}_{2}$ & 9.8 \\
\hline
\end{tabular}

Under production conditions the flowsheet shown in Figure 2 is recommended. The flowsheet includes the following operations:

- $\quad$ ore grinding and classification up to $65-70$ per cent

- $74 \mu \mathrm{m}$

- the scalping of the material prior to separation

- high-intensity magnetic separation of the ore in two stages (double cleaning of the non-magnetic product in each stage); magnetic product from the first stage is used as the feed in the second stage

- the thickening and the filtration of the concentrate.

It is recommended to use the 6-ERM-35/135 rotor-type high- intensity magnetic separator equipped with grooved plates in the upper and middle rotors, and the combination matrix in the lower rotor.

MAGNETIC SEPARATION OF LIMONITE ORES FROM THE KERCH DEPOSIT

The existing processing plant treats two types of the limonite ore: "brown" ore, i.e. coarsely disseminated oolite ore and "tobacco" ore which is finely disseminated with a cement binding. The beneficiation method used is jigging.

With 97:3 ratio of brown to tobacco ores (1970) in the mix, the concentrate produced by this technique contained 45.8 per cent of $\mathrm{Fe}$ at 75.1 per cent recovery. With 50:50 ratio of brown to tobacco ores (1985) in the mix, the grade of the concentrate decreased down to 44.6 per cent and the recovery of iron dropped to 63.1 per cent.

With a further reduction in the concentration of the brown ore down to 20 per cent, a continuous decrease in the grade to 43.8 per cent is expected. At the same 


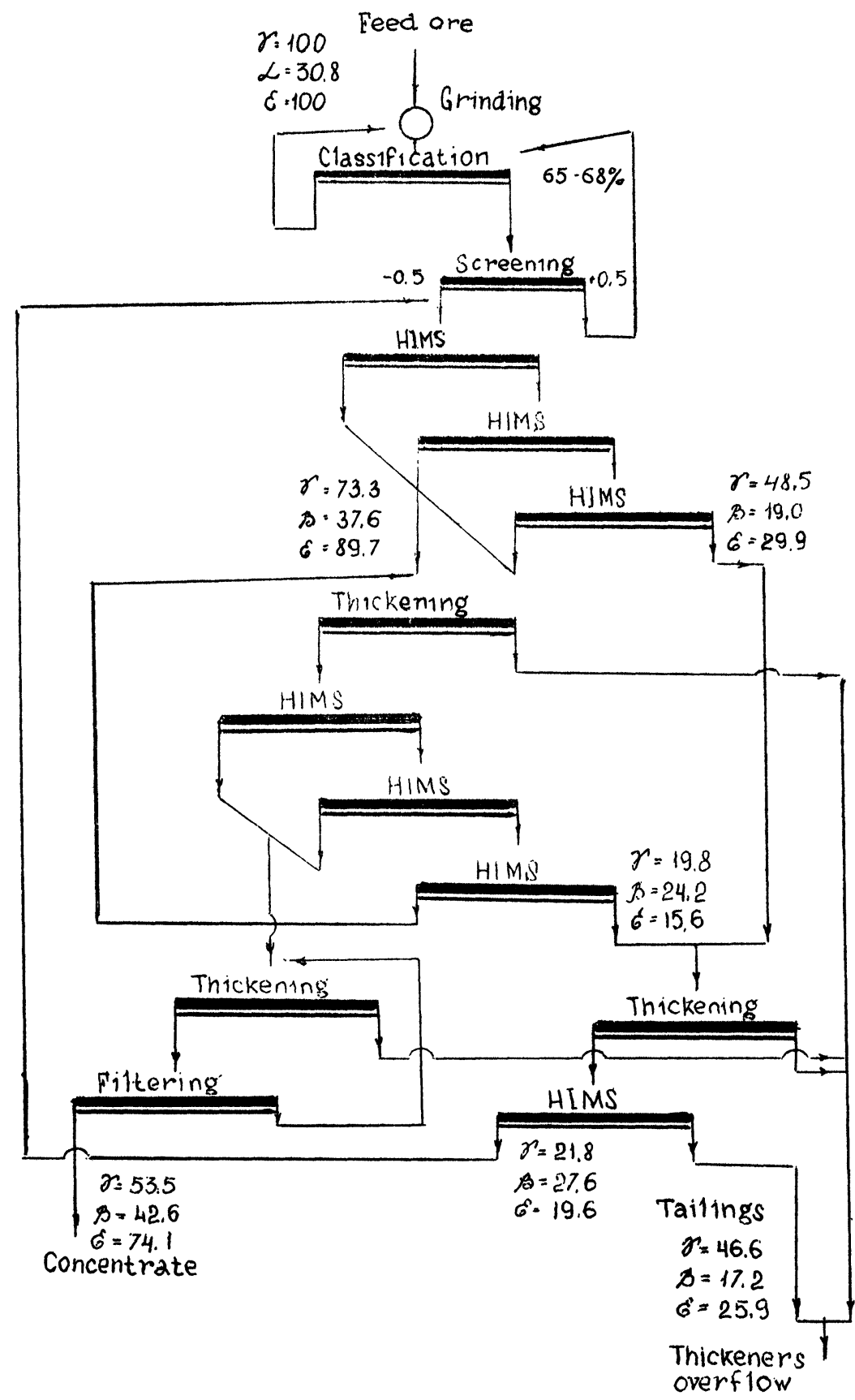

FIGURE 2 The flowsheet for the beneficiation of the Kremikovsky ore $\gamma$ - mass yield (\%), $\alpha$ - head grade (\%)

$\epsilon$ - recovery (\%), $\beta$ - grade (\%) 


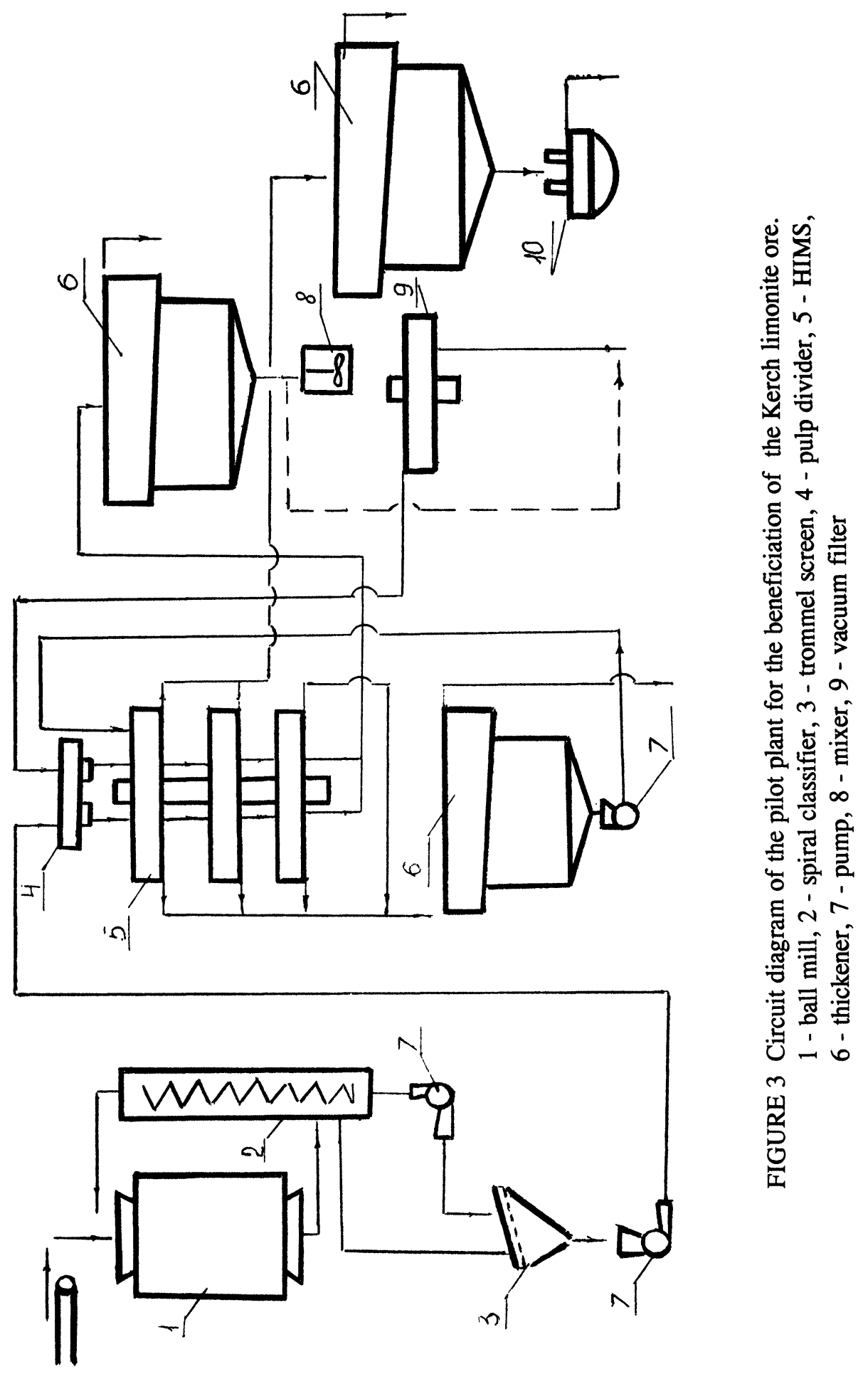


time, the recovery is expected to drop to 59.4 per cent. Evaluation of these data indicates that the tobacco variety of the limonite ore is not beneficiated by jigging.

In order to find an effective technology for beneficiation of tobacco ores, laboratory and pilot-plant tests of two samples taken from the operating open pits were conducted.

The iron content in the samples was 39.9 per cent and 38.5 per cent, respectively. The metallic part of the ore is represented by hydrogeothite in fine flaky form. The specific gravity of the ore is $3360 \mathrm{~kg} / \mathrm{m}^{3}$ and the specific magnetic susceptibility is equal to:

$5.3 \times 10^{6} \mathrm{~m}^{3} / \mathrm{kg}$ at the magnetic field of $80 \mathrm{kA} / \mathrm{m}(1 \mathrm{kOe})$

$1.5 \times 10^{6} \mathrm{~m}^{3} / \mathrm{kg}$ at the magnetic field of $800 \mathrm{kA} / \mathrm{m}(10 \mathrm{kOe})$.

Chemical composition of the ore is shown in Table VII.

Under the laboratory conditions, the gravity analysis was made and gravity concentration of the feed ore by washing and jigging was carried out. Similarly, magnetic separation of the feed ore, of the underflow after washing and of the jigging tailings was performed.

TABLE VII Chemical composition of the ore

\begin{tabular}{lr} 
Compound & Percentage \\
\hline $\mathrm{Fe}$ & 38.5 \\
$\mathrm{FeO}$ & 3.3 \\
$\mathrm{Fe}_{2} \mathrm{O}_{3}$ & 51.4 \\
$\mathrm{SiO}_{2}$ & 19.75 \\
$\mathrm{TiO}_{2}$ & 0.21 \\
$\mathrm{Al}_{2} \mathrm{O}_{3}$ & 2.73 \\
$\mathrm{CaO}$ & 1.97 \\
$\mathrm{MgO}$ & 0.67 \\
$\mathrm{MnO}$ & 1.23 \\
$\mathrm{~K}_{2} \mathrm{O}$ & 0.28 \\
$\mathrm{Na}$ & $\mathrm{O}$ \\
$\mathrm{P}_{2} \mathrm{O}_{5}$ & 0.14 \\
$\mathrm{~S}$ & 2.26 \\
$\mathrm{LOI}$ & 0.28 \\
\hline
\end{tabular}


The gravity analysis showed that with 3 to $0 \mathrm{~mm}$ size it is possible to separate only a part of the high-grade concentrate. The main mass of 50 per cent $\mathrm{Fe}$ can be produced at the grinding size up to $0.5-0 \mathrm{~mm}$.

Microscopic observation of products after the gravity analysis indicated that the liberated oolites were concentrated in $-1+0.25 \mathrm{~mm}$ size fractions. High-grade and low-grade intergrowths are present in $-3+1 \mathrm{~mm}$ size fraction, non-metallic cement prevails mainly in $-0.25 \mathrm{~mm}$ size fraction.

Comparison of different flowsheets for beneficiation of tobacco ore using pilotplant circuits with capacities of $0.1 \mathrm{t} / \mathrm{h}$ and $2 \mathrm{t} / \mathrm{h}$ showed that the best process parameters were obtained with the flowsheet which includes crushing the feed ore to 5-0 $\mathrm{mm}$, washing the crushed ore in a classifier, screening the underflow after washing at $1 \mathrm{~mm}$, separation of the final concentrate into undersize, regrinding the oversize to 96 per cent $-5 \mathrm{~mm}$, HIMS of the ground product combined with the overflow after washing, concentrate thickening and filtering. The flowsheet is depicted in Figure 3.

TABLE VIII Chemical composition of the concentrate

\begin{tabular}{lr} 
Compound & Percentage \\
\hline $\mathrm{Fe}$ & 46.5 \\
$\mathrm{FeO}$ & 4.0 \\
$\mathrm{Fe}_{2} \mathrm{O}_{3}$ & 62.0 \\
$\mathrm{SiO}_{2}$ & 11.2 \\
$\mathrm{TiO}_{2}$ & 0.11 \\
$\mathrm{Al}_{2} \mathrm{O}_{3}$ & 2.73 \\
$\mathrm{CaO}$ & 1.51 \\
$\mathrm{MgO}$ & 0.44 \\
$\mathrm{MnO}$ & 1.55 \\
$\mathrm{~K}_{2} \mathrm{O}$ & 0.17 \\
$\mathrm{Na}$ & 0.04 \\
$\mathrm{P}_{2} \mathrm{O}_{5}$ & 2.9 \\
$\mathrm{~S}$ & 0.2 \\
$\mathrm{LOI}$ & 13.35 \\
\hline
\end{tabular}

Two types of HIMS separators were used in the tests: a rotor-type separator with horizontal magnetic field and with separation in a pulp flow (in which the pulp is fed directly into the air gaps between the matrix elements); and a carousel-type 
separator with vertical magnetic field and with separation in aqueous medium (in which case the matrix is pre-filled with water).

Magnetic flux density in the separation zone was 1.2 to $1.7 \mathrm{~T}$. The grooved plates and expanded metal sheets were used as a matrix. The unit with separation in aqueous medium which offers the treatment of both grainy material and of the slimes after washing was the most efficient machine for a given application.

The chemical composition of the concentrate is shown in Table VIII. The recovery of iron into the concentrate was 55 per cent.

\section{CONCLUSIONS}

It was shown that high-intensity magnetic separation can be used to treat limonite iron ores from two deposits. The process equipment that makes the application of this technology to various deposits of limonite ore possible has been developed in the Ukraine.

\section{ACKNOWLEDGMENTS}

The authors are grateful to L.G. Tsurupa and Yu. V. Narizhnyak for their participation in the experiments.

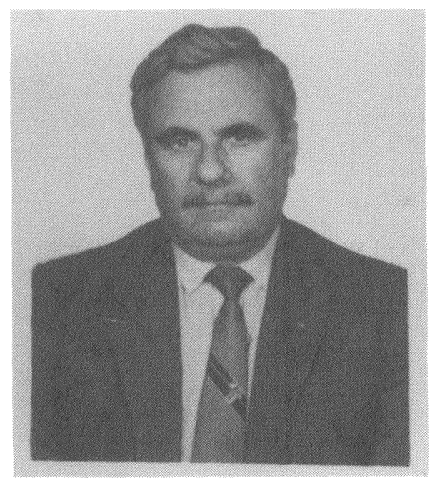

Vladimir M. Maliy, Candidate of Technical Sciences (PhD), senior research officer, was born in 1934. After graduating from the Krivoy Rog Mining Institute in 1956 he worked at the Olenogorsk Beneficiation Plant. From 1960 to 1979 he was employed as a chief metallurgist at the Krivoy Rog Central Mining and Beneficiation Complex. For the last 13 year he has held a position of the head of a department at the research and development institute Mekhanobrchermet.

Dr. Maliy's main scientific interest lies in the beneficiation of weakly magnetic difficult-to-upgrade iron ores. He is a chief technologist of the project on oxidized ores, currently under construction at the Krivoy Rog Mining and Beneficiation Complex. He is an author of numerous papers, including contributions to the VIIIth, XVIth (Stockholm) and XVIIth (Dresden) International Mineral Processing Congresses. 


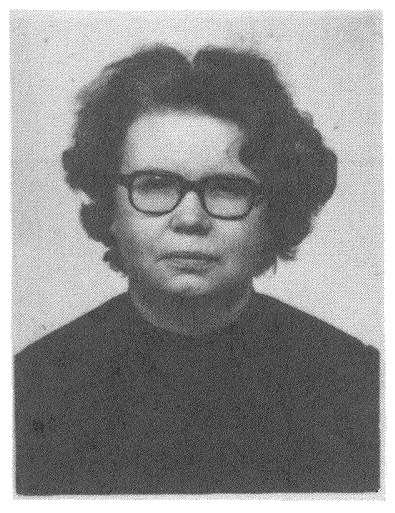

Irina P. Bogdanova, Candidate of Technical Sciences $(\mathrm{PhD})$, senior research officer, was born in 1932. After graduating in mineral processing from the Faculty of Mining of Non-Ferrous Metals and from the Gold Institute in Moscow in 1955, she worked as a process engineer at the Research Centre in Karl- Marx-Stadt (East Germany), and later at the Mekhanobrchermet Institute. Dr. Bogdanova obtained her PhD degree from the Mining Institute of the Soviet Academy of Sciences. Presently she is a chief researcher specializing in beneficiation of ferrous metal ores by magnetic techniques.

Keywords: high-intensity magnetic separation, magnetic separator, limonite ore, matrix, grinding. 